investigators of plant histology: Prof. Russow. The subject is that of the existence of intercellular protoplasm.

Dr. Schaarschmidt has already given the literature. The only other observation with which I am acquainted is that of Prof. Frommann ("Zur Lehre von der Bildung der Membran von Pflanzenzellen"-separate pamphlet) who finds in the intercellular spaces of the young stem of Ricinus communis, protoplasm ; starch grains, and chlorophyll grains.

The observations as to the existence of intercellular protoplasm depend chiefly upon the staining reactions of iodine and sulphuric acid or chlor. zinc. iod. The cell wall turns blue, or remains yellow as the case may be : the protoplasm, and in certain cases a substance; in or lining the intercellular spaces, stains dark brown. Or again in some instances-e.g., the rhizome of Aspidium filix masthe substance in the intercellular space remains uncoloured. Other observers have employed other staining reagents after swelling with sulphuric acid and chlor. zinc. iod.-e.g., saffranin, eosin, or anilin blue - and in this case a colouration is observed of the protoplasm on the one hand and of the intercellular space substance on the other.

Dealing first with the iodine and sulphuric acid or chlor. zinc. iod. method, it is obvious that, besides the protoplasm which assume; the well-known dark brown colouration, any lignified, cuticularised or suberised membranes would react in the same way, and in the case of one of Berthold's (Ber. d. Deut. Bot. Gesell.) examples, e.g., young stem of Ligustrum vulgare, the substance which so markedly stains, does actually consist of the external membrane of the intercellular space, which towards the free surface has undergone changes associated with partial lignification (Gardiner, Proc. Camb. Phil. Soc., Nov. Ioth, 1884), as can be readily proved by treating a section with aniline chloride and hydrochloric acid, when the well-known gold yellow reaction of lignified tissue appears. In the same way the substance which does not stain with iodine and sulphuric acid might be of a mucilaginous nature, and like the mucilage of the external portions of the wall of the seed of Ceratonia siliqua give the same reaction, viz., remain uncoloured. But there are cases which are not so easy to deal with, as I have stated elsewhere (Proc. Camb. Phil. Soc., Feb. I Ith, I884), I found that the Hofmann's blue which I had so successfully employed for demonstrating the existence of protoplasmic filaments in the pit-closing-membrane stained not only protoplasm but also certain forms of mucilage. Like Russow (Sitzber. $d$. Dorpat. Naturfor., Sept., 1883), I thought at first that in Aucuba Japonica I had discovered the existence of intercellular protoplasm, but I observed later on that this staining substance could be seen to arise as drops on the external walls and that these drops went blue with iodine : thus demonstrating that they were not protoplasm but mucilage. I therefore made experiments with the methylene blue which I had found (Phil. Trans., part iii., I883) to be so useful as a stain for the cell wall, and so differentiating in its action. (A solution is made in water containing a trace of alcohol ; the solution being diluted with water before use. The section freed from alcohol by repeated washing, is left to stain for about 20 seconds, washed and mounted in water). I further found that methylene blue stains equally well, all substances formed by the degeneration of cellulose walls, such as mucilage and the like. So while Hofmann's blue stains protoplasm and mucilage, but not cell wall, methylene blue stains cellwall and mucilage but not protoplasm. Thus the cell-wall and protoplasm may be readily discriminated in a very satisfactory manner, and without this reaction it would indeed be hard to distinguish the two. Many dyes behave like Hofmann's blue so far as the staining of the mucilage is concerned, and I have little doubt but that eosin resembles it in this respect, though not such a good differentiating stain for the protoplasm. In the course of all my experiments, which I have repeated several times,
I have never found intercellular protoplasm but often intercellular mucilage. In all cortex tissues which are often remarkable for their mucilaginous character -e.g., Viscum, Fraxinus, Ilex-mucilaginous degeneration of the free cell-walls very usually occurs, which often-e.g., Ilex, Viscum-extends even to the whole middle lamella. In Aspidium filix-mas, Blechnum Braziliense and other ferns, theso-called cuticularised threads (cuticularfädèn) are in reality rods consisting mainly of mucilage which arise as drops on the free surface of the cell-wall and increase in length by repeated basipetal formation. I do not therefore find nyself able to allow of the existence of intercellular protoplasm.

As to the middle lamella being protoplasm I can only refer to the statements $I$ made with regard to Frommann and Elsberg's researches (Quart. Jour. Mic. Sci., March, I883) and I share fully in the opinion of Prof. Russow ("Ueber die Auskleidung der Intercellularen," Sitzber. d. Dorpat. Naturfor., August, I 884) that if such were the case it is clear that we could have no such thing as a mass of tissue resisting great stress. The cells cannot be connected together by protoplasm. As to the existence of the intercellular chlorophyll grains of which Dr. Schaarschmidt speaks, and the chlorophyll grains and starch grains observed by Prof. Frommann, I also share Prof. Russow's view (loc. cit.) that the above investigators must have been deceived by some abnormal appearance, for what could be the physiological significance of such a phenomenon? The full details of my researches on the subject will, I hope, shortly appear in the Quarterly Journal of Microscopical Science.

WALTER GARDINER

Botanical Laboratory, Cambridge, February Io

\section{THE BANGOR LABORATORIES}

$\mathrm{THE}$ following is a description of the Laboratories of Univerrsity College, Bangor, which were opened by Sir William Thomson on the 2 nd inst. The illustration shows the ground floor arrangement; in the upper floor are a magnetism-room and an optical gallery.

The new physical and chemical laboratories occupy the site of the old stables and coach-houses of the "Penrhyn Arms Hotel," which is now used as the main building of the College; and, to lessen expense, a plan has been adopted by which the old walls are, as far as possible, taken advantage of for outside walls and partitions. To utilise the available space to the utmost it was decided to roof in the whole area, which measures about $\mathrm{I} 20$ feet by 80 feet. This area is bounded on the east by the main building of the College; on the south by a private road which runs nearly parallel to the Shrewsbury and Holyhead turnpike road, and gradually ascends until opposite the laboratories, the ground is about 20 feet above the level of the turnpike; on the west and north by the private grounds of the College.

At the extreme east end of the south front of the laboratory buildings is a wide door opening into a vestibulc, from which a passage leads north, and terminates in a wider space or hall. From this hall a long corridor runs parallel to the south front, dividing the floor space into two nearly equal parts. Of these the southern is set apart for physics, the northern for chemistry.

The physical and chemical lecture-theatres $(23,4 \mathrm{I})$ are of the same size, 32 feet square and 19 fcet high, and are placed side by side with the corridor as a separating space between them. The internal arrangements are nearly the same in both rooms. The students' entrances are opposite one another in the corridor. The benches, eight in number, rise from the front to the back of the room, and front toward the west. The lecture-tables arc placed about 4 feet from the front bench, and between each table and the west wall there is a clear space between 7 and 8 feet wide. In the physical lecture-theatre the table is supported on four pillars of masonry, and is en- 
tirely independent of the floor of the room. The tables differ somewhat in their arrangements, one being designed specially for chemical, the other for physical, work. Both have been fitted with the most recent improvements, and some novel appliances.

At the south end of the physical lecture-theatre, opposite the end of the lecture-table, is a large window filled with plate glass, and projecting so as to give additional space within the room for experimental work. A stand for a heliostat is fixed outside, and a table for optical instruments will be placed in front of the window inside.

An open space, extending to the ridge, and about 12 feet square, has been left above the centre of the physical lecture-table, and in this way a clear height of about 30 feet has been obtained for long pendulums, vibrating cords, \&c. A gallery surrounds this space near the top to allow the beams, from which such appliances are suspended, to be easily reached.

By means of blinds, working on spring rollers controlled by cords from one place near the table, the windows of each lecture-theatre can be completely darkened in an instant.

A passage leads from each lecture-theatre to the space beneath the benches, which has been utilised for storage, and gives access to two rooms behind. In the physical department these are diagram-room and store-room (2r, 22); in the chemical department store-room and class museum $(43,42)$, respectively.

In each department the space intervening between the lecture-theatre and the public laboratory is occupied with the professor's private room and laboratory, and the preparation and apparatus rooms. On the physical side, im-

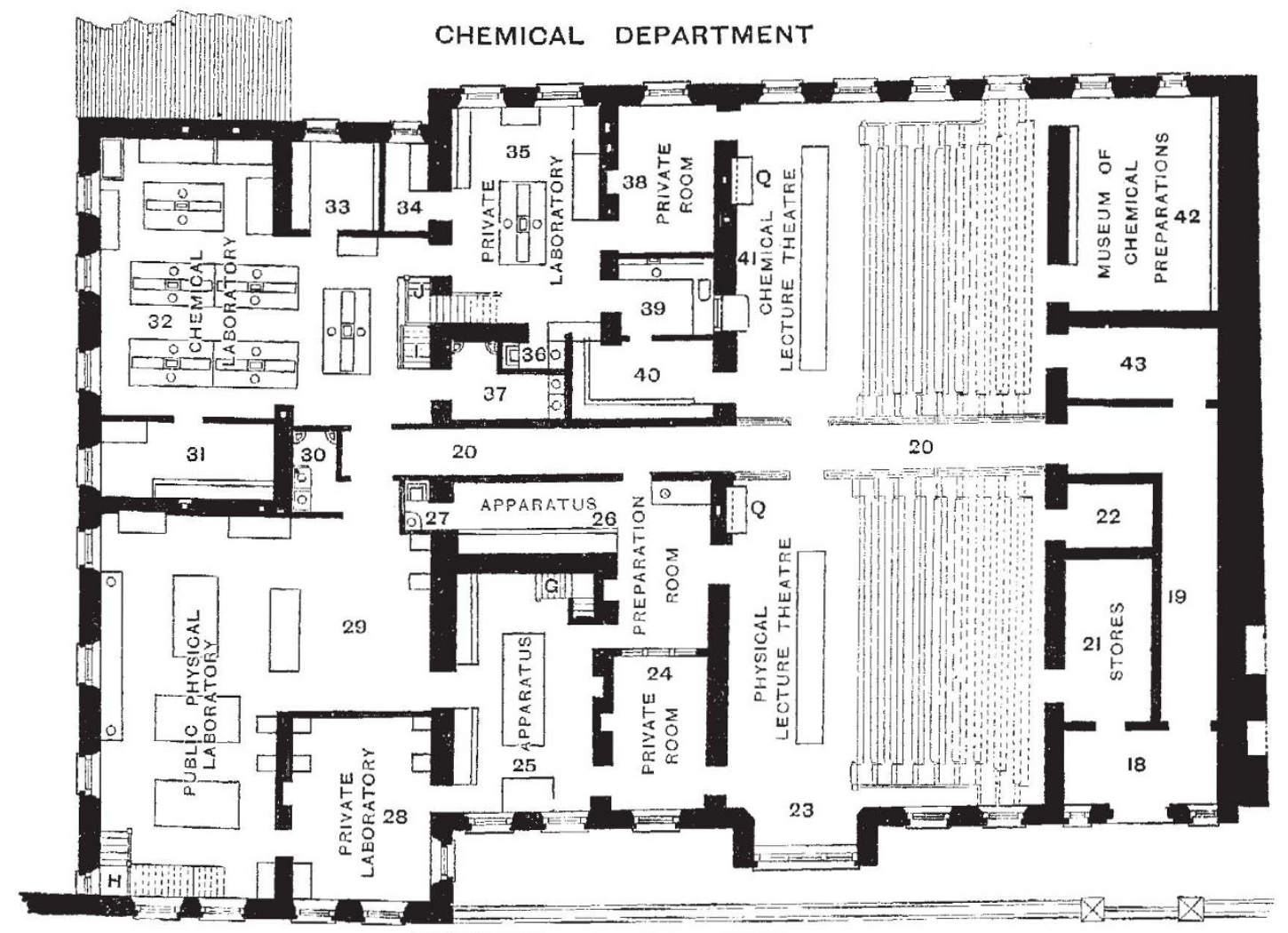

PHYSICAL DEPARTMENT

The New Laboratories of University Co!lege, Bangor.

mediately to the west of the lecture-theatre, are the private room and preparation room $(24,26)$, which communicate directly with the lecture-theatre. Beyond the private room is the apparatus room (25), which overlaps the preparation room, and communicates directly with it. The preparation room is L-shaped, one limb of the $\mathrm{L}$ running back along the north wall of the apparatus room. This part of the room is open to the roof, to allow the room to be lighted by a window at the west end, placed above the level of the western part of the building, and by a large skylight, and is fitted along one side with cases as a supplementary apparatus room. An available height of about 25 feet is obtained in front of these cases, and is designed for elasticity experiments. A gallery over the window allows the roof above this part of the room to be reached by means of a ladder. The limb of the L. immediately behind the lecture room is fitted with a work-table and provided with a fireplace, as a preparation room for the lecture experiments.

To the west of the apparatus room is the private laboratory (28), about 20 feet by 18 feet, communicating with the preparation room and private room on one side, and with the public laboratory (29) on the other. In the south-west corner of this room a slate balance table has been built into the wall, and near the other end of the room slate tables have been fixed to the wall for galvanometers and electrometers. A single work-table, fitted with gas, occupies the centre of the room, and a smaller work-table with gas and water the south-east corner.

The general physical laboratory (29) is a large room over Iooo feet square in area, rumning along the west end of the space allotted to the physical department. The 
student's entrance is from the corridor, and adjoining this entrance is a lavatory and cloak-room (30) for their use. The laboratory is fitted with work-tables for about twenty students. Along the west wall is a long work-table, fitted with gas and water. The space below this table is divided into cupboards and drawers for the use of students. On the north wall a draught chamber, and combined heating store and sand bath, of novel design, have been provided, and at different positions slate slabs for galvanometers, \&c., have been fixed to the walls as in the private laboratory. The roof is left open to add to the height of the room, and for convenience for experimental arrangements. The room is lighted by windows in two sides, and by a row of large skylights on each side of the ridge.

A staircase, G, leads from the apparatus room to two rooms on the second floor. One of these has been constructed without iron to ensure a uniform magnetic field. No magnets or a large mass of iron will be stored below, and the room will be available for absolute electric measurements. The other room is a gallery about 37 feet long and so feet wide, constructed for optical and photometric work.

A second stairway leads to a small room communicating with the gallery above the lecture table, and with a flat space on the roof which has been constructed as a station for observations of atmospheric electricity. The collector of electricity will be placed outside on the flat roof, and connected with a station electrometer in the small room below.

A stair, $\mathrm{H}$, at the south end of the general physical laboratory leads to some valuable rooms in the basement, which have been set apart for practical electricity, workshop (with lathe and forge), magnetic room, battery room, store room, \&c.

Returning to the chemical side, the preparation and apparatus rooms $(39,40)$ occupy the position corresponding to that of the preparation and elasticity rooms on the physical side. The preparation room is fitted with proper work-tables, and communicates with the lecture-theatre by a sliding panel. The private laboratory (35) corresponds to the apparatus room of the physical department. It is fitted with a work-table for four persons, and a large draught chamber and sand bath, and communicates with a special balance room (34) on the west side. The general chemical laboratory (32) corresponds in position with the physical laboratory, and is fitted with work-tables for twenty-four students. These tables have been constructed according to a special design embracing all the most recent improvements. Around the north end of the laboratory have been placed sand baths, draught chamber, large distilling table, sink and table for water and air baths. A portion of the south end of the laboratory has been partitioned off and fitted up as a combustion and blowpipe room(3I). At the north end a balanceroom (33) has been fitted up, and in this room, as well as in the private balance room, the floor is completely isolated from the laboratories, and the tables for the balances are supported on strong brackets firmly fixed to the stone walls. The lighting of the laboratory is managed in the same way as that of the physical laboratory, the skylights along the east side of the ridge of the roof being made to open.

A staircase, J, leads from the general laboratory to the first floor of the chemical department, which is occupied with rooms specially designed and fitted for photographic, gas analysis, and spectroscopic work respectively. A ladder leads to a flat roof for experiments which require to be made in the open air. A second stair, 1, leads from the general laboratory to the basement, where there is a rough operation room, joiners' shop, and metallurgical room.

The arrangement of the rooms and the construction of the lecture tables, work-tables, and other fittings have been carried out by Mr. Richard Davies, architect, Bangor, under the direction and superintendence of Profs.
A. Gray (Physics) and J. J. Dobbie (Chemistry), and in accordance with sketch plans furnished by them.

The addresses on Scientific Laboratories which Sir William Thomson delivered on the opening of the above laboratories we shall give in our next number.

\section{NOTES}

THE Geological Society has this year awarded the Wollaston Medal to Mr. George Busk for his researches on Fossil Polyzoa and on Pleistocene mammalia; the Murchison Medal to Prof. Ferdinand Roemer, the eminent palæontologist of Breslau ; the Lyell Medal to Prof. H. G. Seeley, for his long-continued work on Fossil Saurians; and the Bigsby Medal to M. Renard, of the Brussels Museum, on account of his petrographical researches.

THE annual meeting of the Paris Academy of Sciences was held on February 23 before a very large audience. M. Rolland, the President for 1884 , was as usual in the chair. $\mathrm{He}$ delivered the customary address, alluding to the members of the Academy who died during the past year, and gave a résumé of the principal scientific facts of the same period. M. Arago (Emmanuel), the eldest son of François Arago, who is French Ambassador to Berne, had come to Paris in order to be present at the delivery of the éloge on his illustrious father, who died thirty years ago. The delay must be attributed to the political career of the Perpetual Secretary of the Academy of Sciences, who, having been a member of the Government of the second French Republic, was not a grata persona to the then authorities. The speech was delivered by M. Jamin, who was one of his successors in the seat he occupied in the section of Physics. M. Bertrand fills his place as Perpetual Secretary. The number of prizes delivered is too great to be reported at full length. We must content ourselves by mentioning the laureates who have worked at questions of general interest. A part of the prize of 6000 francs for progress in efficiency of naval forces has been awarded to the Hydrographic Mission to Tunisia, and to a work of M. Baills on artillery. The Monthyon prize has been awarded to $M$. Riggenbach, a Swiss engineer, for his railways in mountainous districts. The Poncelet prize, for progress in mathematics, to M. Houel, for the whole of his works. The Lalande prize, for astronomy, to M. Radau, for a memoir on refractions; and the Salz prize, for the same science, to M. Gurzel, for a disquisition on ancient eclipses in order to determine the value of the secular acceleration of the motion of the moon. The Tremont prize has been awarded to $M$. de Taste for his works on meteorology. M. Marsault has received a gratification of 1500 francs for his studies on lamps for miners. This gentleman is director of the Bessages collieries. The cholera prize was not awarded. M. Durand-Claye, an engineer of the Municipal Service of Paris, who is a strong supporter of the system called "tout à l'égout," took a prize of statistics for his researches on diffusion of typhoid fever.

Mr. Alexander Agassiz has resigned his position as a Fellow of Harvard College, and Science states that his resignation was naturally accepter by the Corporation with great reluctance. The Bulletin of the University just published contains the formal notes taken at the meeting of October 24, which state "that the wide range of his sympathies and interests, the confidence and affection which he inspired, and the varied information which he possessed both as a man of business and as a man of science, made his services as a fellow of singular value to the University ; that his great gifts within the past thirteen years to the scientific departments, and especially to the Museum of Comparative Zoology, which amount to more than half a million of dollars, make him one of the chief benefactors of the University, and entitle him to its profound gratitude." 